\title{
Archaeological Testing of the New Plaza at Mission San Francisco de la Espada (41BX4), San Antonio, Texas
}

Kevin J. Gross

Center for Archaeological Research

Follow this and additional works at: https://scholarworks.sfasu.edu/ita

Part of the American Material Culture Commons, Archaeological Anthropology Commons, Environmental Studies Commons, Other American Studies Commons, Other Arts and Humanities Commons, Other History of Art, Architecture, and Archaeology Commons, and the United States History Commons

Tell us how this article helped you.

This Article is brought to you for free and open access by the Center for Regional Heritage Research at SFA ScholarWorks. It has been accepted for inclusion in Index of Texas Archaeology: Open Access Gray Literature from the Lone Star State by an authorized editor of SFA ScholarWorks. For more information, please contact cdsscholarworks@sfasu.edu. 


\section{Archaeological Testing of the New Plaza at Mission San Francisco de la Espada}

(41BX4), San Antonio, Texas

\section{Creative Commons License}

\section{(c) (1) \&}

This work is licensed under a Creative Commons Attribution-NonCommercial 4.0 International License 


\title{
Archaeological Testing of the New Plaza at Mission San Francisco de la Espada (41BX4), San Antonio, Texas
}

\author{
Kevin J. Gross \\ with a contribution by Johanna M. Hunziker
}

Robert J. Hard and C. Britt Bousman

Principal Investigators

Texas Antiquities Committee Permit No. 1743

${ }^{\complement}$ copyright

Center for Archaeological Research

The University of Texas at San Antonio

Archaeological Survey Report, No. 262

1997 
The following information is provided in accordance with the General Rules of Practice and Procedure, Chapter 41.11 (Investigative Reports), Texas Antiquities Committee:

1. Type of investigation: Testing

2. Project name: Mission Espada

3. County: Bexar

4. Principal investigators: Robert J. Hard and C. Britt Bousman

5. Name and location of sponsoring agency: San Antonio Missions National Historical Park, 2202 Roosevelt Avenue, San Antonio, Texas 78210

6. Texas Antiquities Committee Permit No.: 1743

7. Published by the Center for Archaeological Research, The University of Texas at San Antonio, 6900 N. Loop 1604 W., San Antonio, Texas 78249-0658, 1997

A list of publications offered by the Center for Archaeological Research is available. Call (210) 458-4378; write to the Center for Archaeological Research, The University of Texas at San Antonio, 6900 N. Loop 1604 W., San Antonio, Texas 78249-0658; e-mail to car@lonestar.utsa.edu; or visit CAR's Web site at http://www.csbs.utsa.edu/research/car/index.htm. 


\begin{abstract}
In October 1996, the Center for Archaeological Research (CAR) of The University of Texas at San Antonio completed archaeological investigations of the eastern portion of the interior compound of Mission San Francisco de la Espada. The archaeological testing was undertaken in advance of the construction of a movie set in the New Plaza of the mission. The staging involved setting up approximately 100 tents, using eight-inch stakes driven about six inches into the ground. Twenty-six shovel tests were excavated across the plaza to locate any culturally sensitive areas which might be affected by the movie set.

Pre-1780 material from the investigated portion of the New Plaza may be earlier trash deposits placed outside of what was then the interior of the compound. A concentration of post-Colonial ceramics in the southern portion of the mission may reflect habitation sites along the south wall throughout the nineteenth and early twentieth centuries. The results of the shovel testing suggest that the northern portion of the New Plaza may contain intact Spanish colonial deposits. However, 6 to 12 inches of fill are currently being added to this portion of the plaza as part of a separate drainage improvement project at the mission. We recommend, therefore, that the northern area be avoided, either entirely or until land modification has been completed. The proposed disturbances will have no effect on Colonial deposits elsewhere in the plaza, and work should be allowed to continue in those areas.
\end{abstract}




\section{Contents}

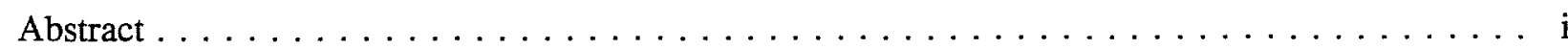

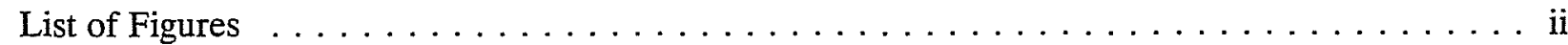

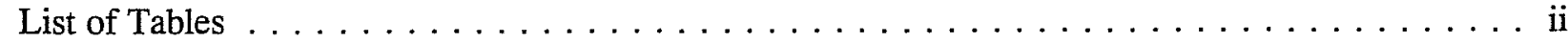

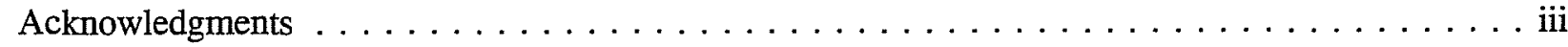

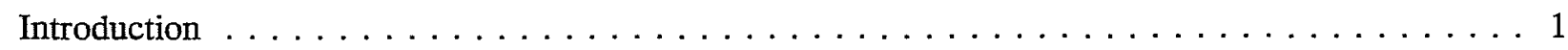

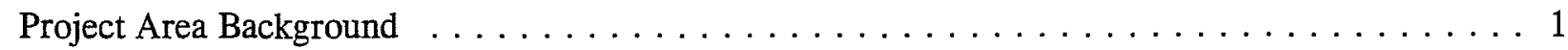

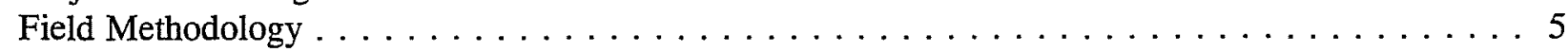

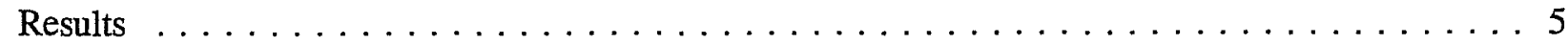

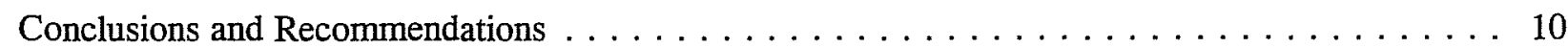

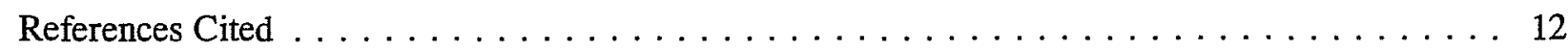

\section{Figures}

1. Location of Mission Espada within the San Antonio Missions National Historical Park. . . . . . 1

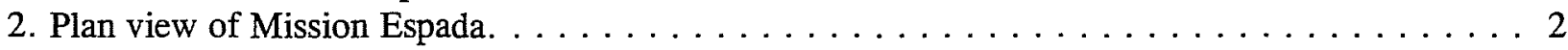

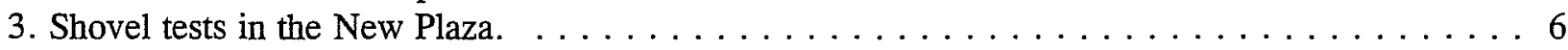

\section{Tables}

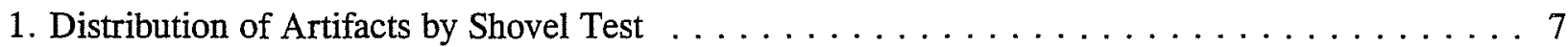

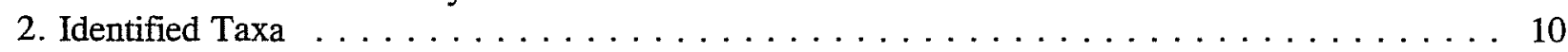




\section{Acknowledgments}

Thanks are extended to John W. Arnn and Bruce K. Moses for their work in the field. Additionally, Bruce's work on the site maps is greatly appreciated. Christopher J. Barnes is thanked for his assistance in the laboratory. Cynthia $\mathrm{L}$. Tennis, small projects coordinator at CAR, is thanked for completing the prefieldwork and for reviewing preliminary drafts of this report. Steve A. Tomka's assistance with the lithics is greatly appreciated. Thanks also to Robert J. Hard, director of CAR, and C. Britt Bousman, associate director of CAR, co-principal investigators, for their guidance and direction throughout the project. Special thanks are reserved for Anne A. Fox, the CAR laboratory director, and Jake E. Ivey, of the National Park Service (Santa Fe, New Mexico), for discussing the structural development of Mission Espada and the artifact distributions. Anne's assistance in the field and laboratory is also greatly appreciated. Finally, Marcie Renner is thanked for preparing the manuscript for final publication. 
. 


\section{Introduction}

In October 1996, the Center for Archaeological Research (CAR) of The University of Texas at San Antonio (UTSA) completed archaeological investigations of the eastern portion of the interior compound of Mission San Francisco de la Espada. The mission is one of four in the San Antonio Missions National Historical Park (Figure 1), under the auspices of the National Park Service (NPS).

The archaeological testing was undertaken in advance of construction of a movie set in the plaza of Mission Espada. The movie company planned to stage a scene for an upcoming film about Teddy Roosevelt and the Rough Riders which involved setting up approximately 100 tents, using eight-inch stakes driven about six inches into the ground. Twenty-six shovel tests were excavated across the section of the plaza to be impacted.

The investigated portion of the compound is frequently referred to as the New Plaza, as it was not constructed until about 1780 when the mission was expanded to its present dimensions. Little is known about the New Plaza's use during the Colonial period (from about 1731-1824). A careful analysis of the distribution of Colonial and postColonial material from this investigation, however, suggests that a pre-1780 dump may have existed outside the then-east gate of the compound in what is now the New Plaza (Figure 2).

\section{Project Area Background}

\section{History}

Numerous construction and reconstruction episodes have been recorded at Mission Espada throughout the Colonial period and then again in the late-nineteenth and early-twentieth centuries. Like other San Antonio missions, Mission Espada was continuously inhabited from the Colonial period until recently. A brief review of the historical and structural development of the mission is necessary to understand the distribution of archaeological deposits. Habig (1968:192-233),
Smith (1980a:2-18, 1980b:36-39), and Winfrey (1965:103-124) should be consulted for more complete histories of the mission. Similarly, Bolton (1915), Chipman (1992), Cook and MacMillan (1980), Jones (1979), Leutenegger and Perry (1980), and Schuetz (1980a, 1980b, 1980c) provide more detailed descriptions of the Spanish colonial period in San Antonio and Texas.

Before being transferred to its present location in San Antonio in 1731, Mission Espada served the

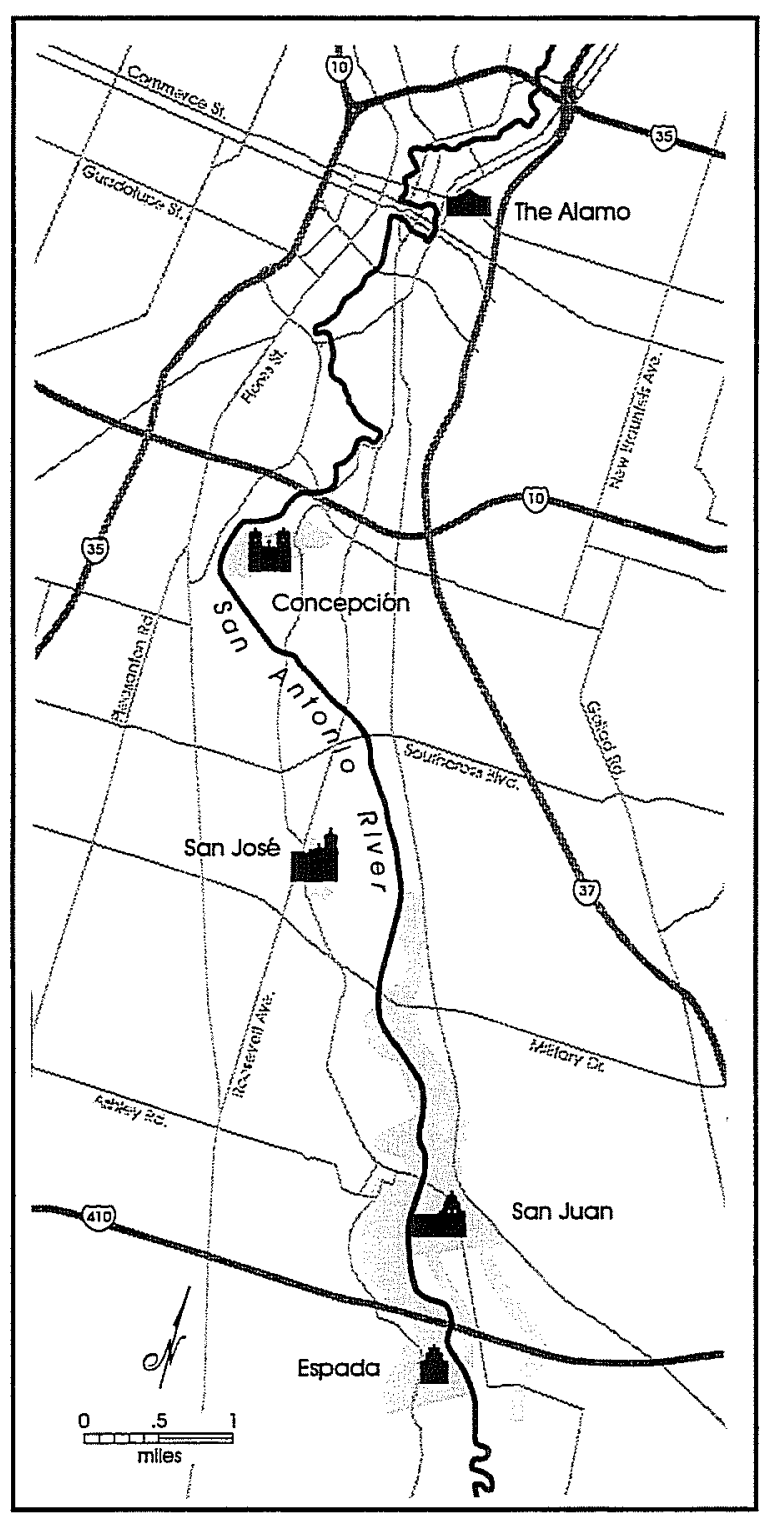

Figure 1. Location of Mission Espada within the San Antonio Missions National Historical Park (shaded area). 


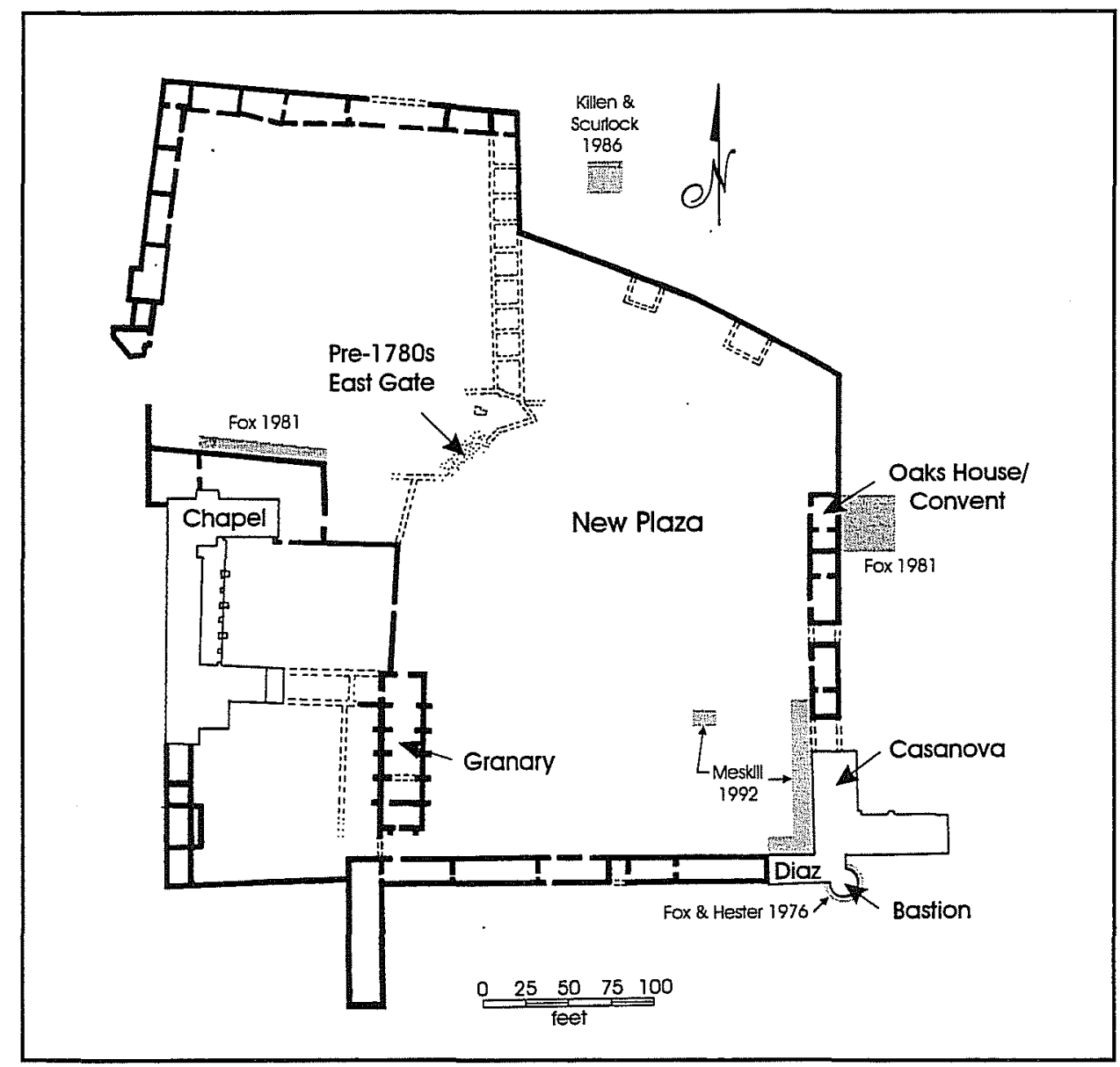

Figure 2. Plan view of Mission Espada showing current configuration and areas of previous archaeological investigations.

Indians of east and central Texas. From 1690 to 1693, the mission, then known as San Francisco de los Tejas, was located near Weches in Houston County, Texas. In 1716 the mission was refounded about 10 miles to the east near Alto in Cherokee County, Texas. The Spanish were forced to abandon the mission in the summer of 1719 after the French invaded east Texas. However, the mission was reestablished in 1721 as San Francisco de los Neches, in the Alto location, and remained functional until about 1729. In 1730 the mission was refounded on the Colorado River, not far from present-day Austin. On March 5, 1731, the mission was refounded to its current location on the west bank of the San Antonio River about nine miles southeast of downtown San Antonio (Figure 1) and renamed Mission San Francisco de la Espada (Habig 1968:192-202; Winfrey 1965:103-107).
Campbell and Campbell (1985:67) suggest that members of at least 25 Native American groups lived at Espada at various times in the Colonial period. Few records documenting Espada's early years (ca. 1731-1752) have been identified, and it is believed that the actual number of groups at the mission was probably much larger. Although the information is incomplete, many of the Indians recorded at Espada are believed to have migrated to San Antonio from south Texas (mostly from along the Nueces River) and northeastern Mexico (along the Rio Grande) (Campbell and Campbell 1985:59-66).

Habig (1968:270) compiled a list of the Indian population at Mission Espada from 1738 until 1815 , revealing that the population fluctuated during the Colonial period. In the early years of the mission, various epidemics killed numerous 
Native Americans and encouraged many survivors to flee the missions. Meissner et al. (1996) argue that the frequent desertions recorded at mission sites may reflect other cultural processes as well. Native Americans may have regarded the missions as a food resource; thus, populations may have fluctuated seasonally as they left to exploit more traditional resources. In any event, Habig's (1968:270) data suggest that the Native American population at Espada increased from 1731 until the early 1760 s when the population climaxed at over 200 . Thereafter, the population continually declined until final secularization. In 1824 only 15 Indian families still resided at Espada (Habig 1968:270).

Ivey et al. (1990) suggest that the compound was not expanded to its present dimensions until ca. 1780. Similarly, Smith (1980a:37), using historical documents and extrapolations from the subsurface foundations recorded during the preliminary reconstruction investigations ca.1934, suggests a four-stage developmental process for Espada. Smith's structural chronology is well argued, but unfortunately, he did not specify years for each expansion phase.

The original convento compound at Espada is believed to have measured 45 varas $(125 \mathrm{ft})$ north-to-south and 50 varas (139 ft) east-to-west (Ivey et al. 1990:102). The friars' cells were located on the west side of the convento compound and would have been about 30 varas $(80 \mathrm{ft}$ ) long. Smith (1980a:37) suggests there may have been a wall on the east side of the small compound (Figure 2).

A separate, enclosed pueblo for the Indian neophytes was probably built on the north side of the convento compound. Ivey et al. (1990:102) believe that the pueblo was originally a group of jacales (vertical-log structures with thatched roofs) laid out as a village. The construction of stone houses and stone walls was not initiated until 1756. Within three years, two walls of stone houses had been completed; it is uncertain, however, which walls were completed. It is likely that the pueblo's south wall was shared with the convento compound's north wall. By 1762 all the pueblo walls had houses constructed of stone (Ivey et al. 1990:206). It is also unclear when the convento compound and the Indian pueblo were joined.

Construction of a sacristy and a never-completed church began between 1740 and 1745. The sacristy served, and continues to serve, as the chapel at Espada. There is record that the foundations for the church were laid (Habig 1968:207). The proposed church's long axis would have been oriented north/south and the sacristy (the current chapel) would have connected to the west transept (Ivey et al. 1990:196). Thus, the church would probably have been directly in front of the current chapel. However, no evidence of the church's foundation have been identified (Anne A. Fox, personal communication 1996).

The convento compound was slowly expanded over time. On the west wall was a two-story structure which included living quarters for the friars upstairs and office and storage space below. The south side of the compound consisted of a kitchen (completed by 1759), an antecocina or food preparation area (completed at an unknown date), a weaving room (completed ca. 1759-1762), and a bread making room (completed by 1772). The granary, which would have formed the southeast portion of the convento wall, was completed by 1772 (Figure 2). It is believed that the granary was used as a church from about 1773 to 1776 (Ivey et al. 1990: 198-199). This granary/ church was destroyed soon after its completion probably because of structural defects (Habig 1968:215). A wall, no longer visible, found north of the granary during Smith's pre-reconstruction fieldwork probably served as the east wall for the entire compound until ca. 1780.

Ivey et al. (1990:200-201) believe several buildings were constructed to the south of the convento compound between 1756 and 1772 . These structures included a stone blacksmith shop, a stone storage building for wool, and three jacales used as a carpenter's shop and for lumber storage. Mission inventories record an oven of mortar and brick, a threshing yard with a stone 
floor enclosed with a stone fence, a chicken house of stone, a corral of wood with a watering trough for pigs, and a series of stone kilns. Archaeologists have identified the latter to the north and east of the compound. The other structures could have been located anywhere adjacent to the mission, including in the area where the New Plaza was later constructed.

During the period from $1776-1780$, the extension of the pueblo compound was undertaken. In ca. 1780 , the declining Indian and increasing Hispanic populations were about equal. By 1815 , in addition to the 27 Native Americans recorded at Espada, 72 Spaniards there (Habig 1968:221). Ivey et al. (1990:205) believe that the pueblo expansion was intended to accommodate the new Hispanic settlers at the mission.

Mission Espada was partially secularized-only "partial" because the priest assigned to Espada, Fray Noceña, continued to take care of the mission and its residents-on July 11, 1794. Each of the 15 remaining Native American families received an $850-\mathrm{x}-555.5-\mathrm{ft}$ plat of land. Eight additional plats, each measuring $111 \times 555.5 \mathrm{ft}$, were set aside as communal lands of the pueblo (Habig 1968:219). In addition to the land, the Native Americans were given the few remaining livestock, tools, and raw materials (i.e., iron, steel, and wood) owned by the mission.

On February 29, 1824, the church and its furnishings were relinquished to the pastor of San Fernando and the representative of the bishop of Monterrey, thereby fully secularizing the mission (Habig 1968:224). During the years that followed secularization the church was neglected, although people continued to live at the mission. In September 1831, José María Letona, the governor of Coahuila and Texas, decreed that all mission property except the churches be sold at public auction and that the monies received be held by the city treasurer of San Fernando (Habig 1968:224).

During the Texas Revolution period, James Bowie and James W. Fannin temporarily used Mission Espada as a headquarters. They arrived with about
100 Americans on October 22, 1835, and had little trouble taking control of the mission square. On October 25, they repulsed an attack on the mission made by about 200 Mexican soldiers (Habig 1968:224; Winfrey 1965:122).

The first reconstruction of the mission was begun in 1858 by Father Francis Bouchu. Bouchu was born in France in 1829 and was ordained in Galveston on March 19, 1855. He eventually lived at Mission Espada, and cared for the buildings and the congregation from around 1873 until 1907. Only the facade and rear wall of the sacristy were standing when Bouchu arrived. He rebuilt the sidewalls on top of the original foundations and added a tin roof to the structure (Habig 1968:225-226). Bouchu also added a wooden floor, doors, a choir loft, benches, and a chancel railing (Winfrey 1965:123).

Several visitors to Espada in the nineteenth century reported that the church and adjacent buildings were in ruins. The accounts did also suggest, however, that two sides of the compound still had inhabited dwellings (Winfrey 1965:122). Even as late as 1890 , Corner (1890) reported that several families lived in houses constructed on top of the compound's foundations. Additionally, photographs taken of the mission in the latenineteenth and early twentieth centuries show houses along the south and north walls (photographs on file, Institute of Texan Cultures [ITC] Library, photo archive numbers 74-769, 82491A, 82-492, and 82-493A). There is also evidence that Peter and Elizabeth Hooge operated the Chavagneaux Store and resided in an adjacent apartment along the south wall ca. 1905 (photograph on file, ITC Library, photo archive number 74-984).

The chapel was closed on January 31, 1909, and a second restoration began in 1911. It was reopened in 1915 (Habig 1968:232). Considerable restoration was also completed by the Work Progress Administration between 1930 and 1932, and between June 1955 and October 1956 (Smith 1980b). A school run by the Sisters of the Incarnate Word was opened in 1915 in the southeastern comer of the compound and was in operation until 
1967. The Sisters also used the Oaks House and an appended room as a convent (Figure 2).

\section{Previous Archaeological Research}

Although comprehensive excavations have not been conducted at Mission Espada, several areaspecific investigations have occurred (Figure 2). Fox (1981) excavated three units in the cemetery adjacent to the north side of the chapel. A probable eighteenth-century living surface was identified in one of the units. Two additional units were excavated in the Oaks House and the adjoining room along the western wall. Fox (1981:6-7) believes the Oaks House was constructed in the nineteenth century on top of the original ca. 1780 foundations. The addition was probably constructed ca. 1934-1957, perhaps when the structure was used as a convent by the Sisters of the Incarnate Word. Only a few Colonial and postColonial artifacts were recovered during this investigation.

The southeast corner of the compound, including the bastion, has received considerable archaeological attention. Fox and Hester (1976) excavated three units adjacent to the interior and exterior walls of the bastion (Figure 2). This investigation documented the original construction of the wall footings to assist with correcting a crack and associated bulge on the east wall of the tower. Although Colonial-period artifacts were recovered, no intact Colonial deposits were identified.

The interiors of the Casanova and Diaz rooms were investigated by Escobedo (1984). These rooms, together with the bastion, form the southeast corner of the compound. Escobedo (1984) excavated almost the entire interior of the Casanova Room. Colonial artifacts and a plastered floor (across most of the room) were identified 21-24 inches beneath the surface. A number of post-Colonial artifacts and features were identified in the overlying strata. A Colonial flagstone floor was identified in the Diaz Room just beneath the wooden floor removed as a part of the excavation. Two additional units were excavated outside the bastion. Meskill (1992) also excavated three units in the southeast corner of the interior compound. Large quantities of Colonial and post-Colonial artifacts were recovered from generally mixed levels. However, one unmixed Colonial level was noted 15-37 inches beneath the surface in a unit excavated along the south wall.

Killeen and Scurlock (1986) excavated five kilns and associated features just north and east of the mission compound. They believe the kilns were constructed and used throughout the Colonial period for the manufacture of lime, probably for plaster.

\section{Field Methodology}

The CAR field team excavated shovel tests (STs) at the intersections of a systematic $50-\mathrm{ft}$ grid to assess the horizontal and vertical extent of archaeological deposits across the entire New Plaza (Figure 3). The grid layout contained four north-south columns, designated A through $\mathrm{D}$, and seven east-west rows, designated 1 through 7 . Twenty-five shovel tests, with a maximum depth of 24 inches, were excavated. One additional shovel test, ST AA1, was excavated five feet west of ST A4 to investigate a possible stone alignment. These tests were excavated in six-inch levels to maximize vertical control. All soil was screened through $1 / 4$-inch mesh wire screen. Artifacts and field notes from this project are curated at CAR.

\section{Results}

The stones in ST A4 did not continue into ST AA1. Thus the stones represent a living surface and not an architectural feature.

Cultural material was recovered from every shovel test except ST B2. In total, 1,208 artifacts were collected from the shovel tests (Table 1). Animal bone was the most frequently collected artifact $(n=758)$; however, as discussed below, the faunal assemblage was extremely fragmented and is, therefore, probably overrepresented by count. 


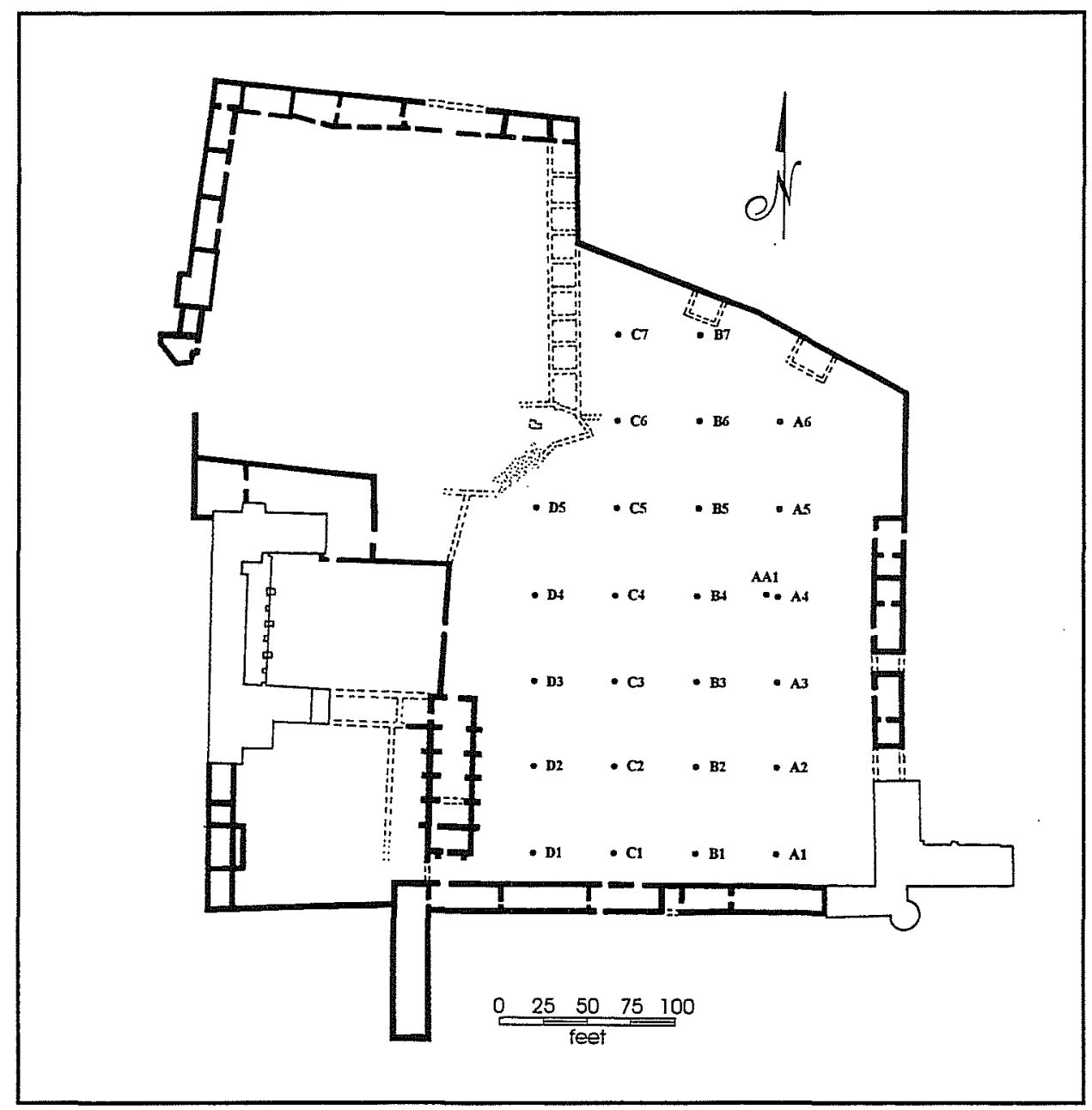

Figure 3. Shovel tests in the New Plaza.

A distinct horizontal separation of Colonial and post-Colonial artifacts was observed. Colonial ceramics and animal bone fragments were found with greater frequency in tests excavated in the northern portion of the mission (Rows 5-7) while post-Colonial ceramics were found with greater frequency in the southern portion of the mission (Rows 1-4). Until the 1780 expansion, the mission's eastern gate would have been just north of Row 5. Brief descriptions of the recovered artifacts follow.

\section{Ceramics}

Unrefined and refined wares are convenient temporal indicators at Spanish colonial sites in south Texas. In general, unrefined earthenwares, including locally produced wares (e.g., Goliad and Valero ware) and wares imported mostly from Mexico (e.g., lead- and tin-glazed wares), were manufactured and used throughout the Colonial period. Refined wares, largely produced in Europe and North America, were introduced into the region in the early 1800s (Hard et al. 1995:46, 71). Detailed chronological and typological descriptions of Colonial ceramics can be found in Deagan (1987), Fox et al. 1976, Goggin (1968), Hard et al. (1995), Ivey and Fox (1981, 1982), and Meskill (1992). Ceramics comprise 12 percent of all artifacts from Mission Espada (or 33 percent of all artifacts, excluding the faunal material). 
Table 1. Distribution of Artifacts by Shovel Tests

\begin{tabular}{|c|c|c|c|c|c|c|c|c|c|c|c|c|c|c|c|c|c|c|c|c|c|c|c|c|c|c|}
\hline 5 & 焉 & 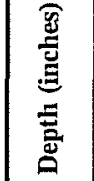 & 苟 & 递 & 氶 & 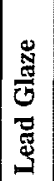 & 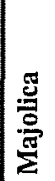 & 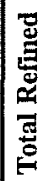 & 莡 & 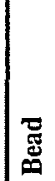 & 氙 & 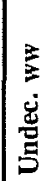 & 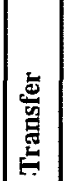 & : & 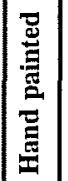 & $\begin{array}{c}\text { 总 } \\
\text { 总 } \\
\text { 出 }\end{array}$ & $\mid \begin{array}{l}\vec{z} \\
\bar{z} \\
\bar{z}\end{array}$ & 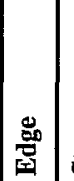 & $\frac{\mathscr{\Xi}}{\text { के }}$ & 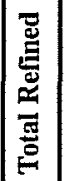 & 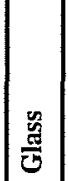 & 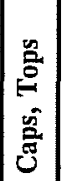 & 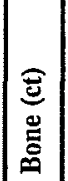 & $\begin{array}{l}\overline{\mathbf{E}} \\
\mathrm{E} \\
\mathrm{E} \\
\mathrm{E}\end{array}$ & 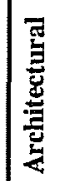 & 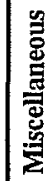 \\
\hline $\mathrm{A} 1$ & 1 & $0-6$ & 1 & & & & & 1 & 1 & & & 1 & & & & & & & & 1 & & & 3 & 6.2 & 1 & \\
\hline $\mathrm{Al}$ & 2 & $6-12$ & & & & & & & & & & 5 & & 1 & 3 & & & & & 9 & 8 & & 7 & 5 & 3 & \\
\hline $\mathrm{Al}$ & 3 & $12-18$ & & & & & & & & & & 3 & & & & & & & & 3 & & & 2 & 0.5 & 1 & \\
\hline $\bar{A} 2$ & 1 & $0-6$ & & & & & & & & & & & & & & & & & & & 2 & & 0 & 0 & & 1 \\
\hline $\mathrm{A} 2$ & 2 & $6-12$ & & 2 & & & & 2 & 1 & & 1 & & & & & & & & & & & & 4 & 1.5 & & \\
\hline$\overline{\mathrm{A} 3}$ & 1 & $0-6$ & & & & & & & & & 1 & & & & 1 & & & & & 1 & 1 & & 0 & 0 & & \\
\hline A3 & 2 & $6-12$ & & 1 & & & & 1 & & & & & & & & & & & & & 2 & & 3 & 6.6 & & \\
\hline $\mathrm{A} 3$ & 3 & $12-18$ & & & & & & & & & & & 1 & & & & & & & 1 & & & 0 & 0 & & \\
\hline$\overline{\mathrm{A} 4}$ & 1 & $0-6$ & & & & & & & 1 & & & & & & & & & & & & 2 & & 0 & 0 & & \\
\hline A4 & 2 & $6-12$ & 1 & & & & & 1 & 2 & & & 1 & & & & & & & & 1 & & & 12 & 2.1 & & \\
\hline A5 & 1 & $0-6$ & 1 & & & & & 1 & 1 & & & & & & & & 1 & & & 1 & 4 & & 5 & 1.4 & 2 & \\
\hline A5 & 2 & $6-12$ & 2 & & & 1 & & 3 & & & & 3 & & & & 1 & & 1 & & 5 & 3 & & 7 & 2.6 & & \\
\hline $\mathrm{A} 5$ & 3 & $12-18$ & 1 & & & & & 1 & & & & & & & & & & & & & . & & 5 & 6.4 & & \\
\hline A6 & 1 & $0-6$ & & & & & & & & & & & & & & & & & & & 2 & & 1 & 0.4 & & \\
\hline A6 & 2 & $6-12$ & & & & & 1 & 1 & & & & 3 & & & & & & & & 3 & I & & 6 & 14 & & \\
\hline$\overline{\mathrm{A} 6}$ & 3 & $12-18$ & & 2 & & 7 & & 9 & & & 1 & & & & & & & & & & & & 59 & 40 & 1 & \\
\hline$\overline{\mathrm{A} 6}$ & 4 & $18-24$ & 1 & & & & & 1 & & & & & & & & & & & & & 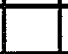 & & 4 & 1.1 & & \\
\hline AA1 & 1 & $0-6$ & & & & & & & & & & 1 & & & 1 & & & & & 2 & 1 & & 0 & 0 & & \\
\hline B1 & 1 & $0-6$ & & & & & & & & & & & & & & & & & & & 8 & & 0 & 0 & 1 & \\
\hline $\mathrm{B} 1$ & 2 & $6-12$ & & & & & & & & & & & & & 1 & & & & & 1 & 3 & 1 & 1 & 2 & 1 & 1 \\
\hline B3 & 1 & $0-6$ & & & & & & & & & & 1 & & & & & & & & 1 & 3 & 2 & 0 & 0 & 1 & \\
\hline B4 & 1 & $0-6$ & & & & & & & & & & 1 & & & 1 & & & & & 2 & 2 & & 1 & 0.5 & & \\
\hline B4 & 2 & $6-12$ & & & & & & & 2 & & & & & & & & & & & & 1 & & 0 & 0 & 1 & \\
\hline B5 & 1 & $0-6$ & & & & & & & & & & & & & & & & & & & 1 & & 112 & 103 & 1 & \\
\hline B5 & 2 & $6-12$ & & & & & & & 1 & & 1 & & & & & & & & & & & & 41 & 33 & & 1 \\
\hline B5 & 3 & $12-18$ & & & & & & & & & & & & & & & & & & & & & 1 & 1 & & \\
\hline B6 & 1 & $0-6$ & & & & & & & 2 & & & & & & 1 & & & & & 1 & 8 & 2 & 0 & 0 & 2 & 1 \\
\hline B6 & 2 & $6-12$ & & & & & & & & & & 1 & & & & & & & & 1 & 2 & & 18 & 11 & & \\
\hline B6 & 3 & $12-18$ & & & & & & & & & & & & & & & & & & & 1 & & 13 & 51 & & \\
\hline B7 & 1 & $0-6$ & & & & & & & 1 & & & 1 & & & & & & & & 1 & 6 & & 9 & 4.8 & 3 & \\
\hline B7 & 2 & $6-12$ & 3 & & & 2 & 1 & 6 & 1 & & & & 1 & & & & & & & 1 & 5 & & 31 & 155 & 3 & \\
\hline B7 & 3 & $12-18$ & 3 & & & 1 & & 4 & & & 4 & 2 & & & & & & & & 2 & & & 23 & 42 & & \\
\hline $\mathrm{Cl}$ & 1 & $0-6$ & & & & & & & 1 & & & 1 & & & & & & & & 1 & 1 & 1 & 0 & 0 & 2 & \\
\hline $\mathrm{Cl}$ & 2 & $6-12$ & & & & & & & & & & & & & 4 & & & & & 4 & 5 & 1 & 0 & 0 & 2 & \\
\hline $\mathrm{Cl}$ & 3 & $12-18$ & 1 & & & 1 & & 2 & & & & & & & & & & & & & & & 9 & 2.6 & 2 & \\
\hline $\mathrm{C} 2$ & 1 & $0-6$ & & & & & & & 1 & & & 2 & & & & & & & & 2 & 9 & 1 & 2 & 0.4 & & \\
\hline $\mathrm{C} 2$ & 2 & $6-12$ & & & & & & & & & & & & & & & & & & & & & 1 & 0.3 & & \\
\hline $\mathrm{C} 3$ & 1 & $6-12$ & & & & & & & 1 & & & & & & & & & & & & 1 & & 0 & 0 & 13 & \\
\hline $\mathrm{C} 3$ & 2 & $6-12$ & & & & & & & & & & & & & & & & & & & 1 & & 17 & 8 & & \\
\hline $\mathrm{C} 4$ & 1 & $0-6$ & 1 & & & & & 1 & 1 & & & & & & & & & & & & & & 0 & 0 & & \\
\hline
\end{tabular}


Table 1. cont.

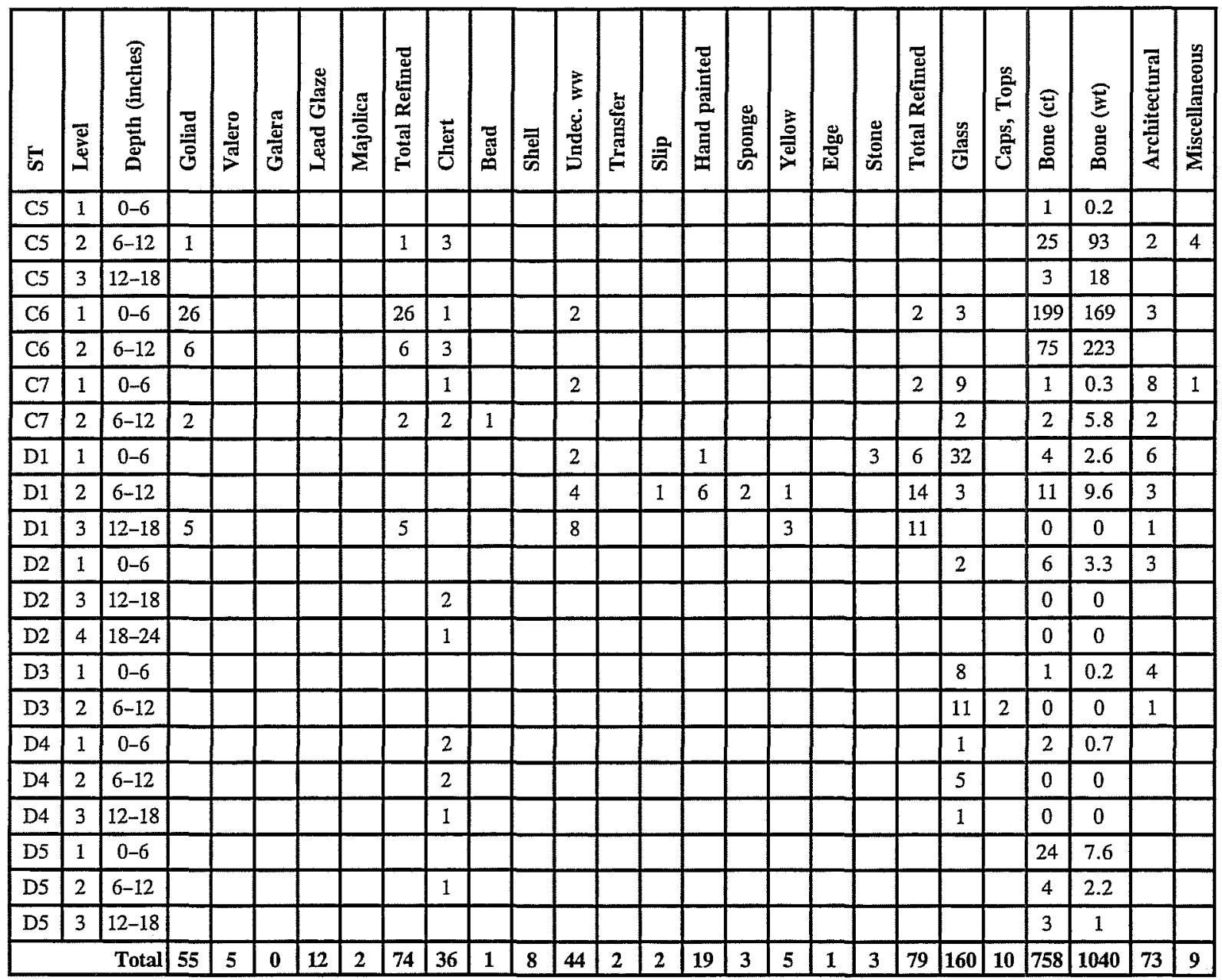

Seventy-four unrefined earthenware sherds were collected, including 55 Goliad sherds, 5 Valeroware sherds, 12 lead-glazed sherds, and 2 majolica sherds. Unrefined wares were found in 13 of the 26 tests.

Seventy-nine refined-ware sherds were recovered. The 44 undecorated whiteware sherds accounted for about 56 percent of the refined assemblage. Two transfer-printed, 2 slipware, 19 hand-painted, 3 sponge, 5 yellowware, 1 edge-decorated, and 3 stoneware sherds were also collected. Refined sherds were collected from 15 of the 26 tests (58 percent).

\section{Chert}

Twenty-eight chert fragments were recovered from 13 shovel tests evenly distributed across the plaza. This lithic assemblage includes 5 pieces of angular debris, 4 platform preparation flakes, 1 early biface manufacturing flake, 2 middle- to late-reduction phase biface manufacturing flakes, 3 biface thinning flake, 5 uniface manufacturing flakes, 1 uniface resharpening flake, 1 expedient tool, and 6 indeterminate flakes. The one tool which appears to be an expedient scraper, is a tertiary, medial flake fragment with micro-flaking from use on one edge (Steve A. Tomka, personal communication 1996). 


\section{Bottle Glass}

Bottle glass $(n=160)$ was the second most frequently collected artifact. Glass was recovered in all tests except STs B2, B5, C4, and C5. Glass was imported to the New World (Deagan 1987; Lister and Lister 1987), including Texas (Gilmore 1969; Tunnel and Newcomb 1969), during the Spanish colonial period. However, based on manufacturing techniques and color, the bulk of the glass in the Mission Espada assemblage appears to be relatively recent. Almost 71 percent of the glass was recovered from tests in the southern portion of the plaza. In fact, the southern tests contained a mean total of 6.6 glass sherds while the tests excavated in the northern portion of the plaza contained an average of 3.9 glass sherds.

\section{Architectural Material}

Forty-one architectural artifacts were collected, including 11 nails, 1 piece of wire, 25 brick fragments, 2 small fragments of cut limestone, 1 daub fragment, and 1 piece of wood. The architectural artifacts were evenly distributed across the plaza.

\section{Faunal Remains \\ Johanna M. Hunziker}

A total of 758 pieces of animal bone, weighing $1,039.74 \mathrm{~g}$, was recovered from 22 of the shovel tests. All bone was identified to the lowest taxonomic level possible using the vertebrate comparative collection at CAR and faunal identification reference guides (Balkwill and Cumbaa 1992; Gilbert 1990; Hillson 1986). Element, portion, and side were recorded for each identified specimen. Amount of weathering and presence of butcher marks were also noted.

Small fragments that were not identifiable to species or genus were identified as mammal, bird, fish, or reptile when possible. Due to the high degree of fragmentation and the limited size of the assemblage, very little in the way of analysis was undertaken other than the listing of identified specimens.

Nearly all the bone was fragmented, thus counts of identifiable and unidentifiable pieces may be misleading. Therefore, in the following discussion weight is used, with the counts included in parentheses. By weight, 26 percent (four percent by count) of the bone assemblage was identifiable to the genus level. Of the remaining bone, 73 percent (91 percent count) was identifiable only as undetermined mammal, one percent (two percent count) as undetermined bird, less than one percent (one percent count) as undetermined fish, less than one percent (less than one percent count) as undetermined reptile (turtle), and less than one percent (two percent count) as unidentifiable fragments.

Identified taxa include cow/bison, goat/sheep, pig, rabbit, chicken, turkey, and catfish (Table 2). Cow/bison accounts for 72 percent of the collection. Distinguishing between cow and bison is very difficult for fragmented bones. The cow/ bison bone is most likely all cow, but the possibility of bison occurring in the Colonial period deposits exists. Specimens that were positively identified as cow were recorded as such, but for the purposes of this discussion all cow and cow/bison is combined. Distinguishing between domestic sheep and goats is also notoriously difficult, so the combined genus of Capra/Ovis is used.

Minimum Number of Individuals (MNI) was calculated using the matching pairs method. This method uses bones in the axial skeleton which occur in pairs, such as humeri and femora, and can only be used on archaeological specimens for which element and side have been identified. The total number of specimens from each side is calculated and is used to determine the minimum number of animals of that particular species it would take to account for the amount of bone in the assemblage. The MNI for each identified taxa is one. 
Table 2. Identified Taxa

\begin{tabular}{|c|c|c|c|c|c|}
\hline \multirow[b]{2}{*}{ Identified Taxa } & \multirow{2}{*}{$\begin{array}{c}\text { Common } \\
\text { Name }\end{array}$} & \multicolumn{2}{|c|}{ Weight } & \multicolumn{2}{|c|}{ NISP } \\
\hline & & Grams & $\begin{array}{l}\text { \% of } \\
\text { Id'ed }\end{array}$ & $\#$ & $\begin{array}{l}\% \text { of } \\
\text { Id'ed }\end{array}$ \\
\hline Bos taurus & Cow & 117.12 & 43 & 3 & 10 \\
\hline Bos/Bison & Cow/Bison & 136.33 & 51 & 18 & 62 \\
\hline \multicolumn{2}{|c|}{ Total cow and cow/bison } & 253.45 & 94 & 21 & 72 \\
\hline Capra/Ovis & Goat/Sheep & 9.91 & 4 & 2 & 7 \\
\hline Sus scrofa & Pig & 0.33 & $\sim 0.1$ & 1 & 3.5 \\
\hline Sylvilagus sp. & Rabbit & 0.31 & $\sim 0.1$ & 1 & 3.5 \\
\hline Gallus domesticus & Chicken & 1.68 & 0.6 & 1 & 3.5 \\
\hline $\begin{array}{l}\text { Me le a g } r i s \\
\text { gallopavo }\end{array}$ & Turkey & 3.11 & 1 & 2 & 7 \\
\hline Ictalurus sp. & Catfish & 0.39 & $\sim 0.1$ & 1 & 3.5 \\
\hline
\end{tabular}

All butcher marks on identifiable and unidentifiable specimens were recorded. The types of butcher marks observed were chop marks made by a hatchet or cleaver, cut marks made by a knife, and impact fractures resulting from breaking open a bone while it is still fresh. Impact fractures usually occur on long bones as a result of breaking them for marrow extraction. Of the identified bone, only four pieces exhibited butcher marks, two cow/bison ribs were chopped, one cow/bison metacarpal had an impact fracture, and one goat/sheep pelvis had a knife cut. Of the unidentified bone, 12 of the mammal specimens had chop marks, one a knife mark, and one an impact fracture. In all, 18 specimens (two percent) showed positive evidence of butchering.

\section{Miscellaneous Items}

Miscellaneous items include a number of artifacts of very recent origin. Ten bottle caps, one rubber shoe sole, five unidentifiable pieces of plastic, and two cloth fragments were recovered. All these items were found from the surface to six inches below the surface.

\section{Conclusions and Recommendations}

Unrefined Colonial period ceramics and animal bone were found with greater frequency in the northern half of the New Plaza. Over 82 percent of the unrefined sherds $(n=61)$, in fact, came from tests excavated in Rows 5-7. A mean total of 26.7 bone fragments with a mean total weight of $(40.7 \mathrm{~g})$ per test was observed in tests excavated in Rows 5-7. Conversely, in tests excavated in the southern half of the compound (Rows 1-4), a mean total of only 3 bone fragments (with a total mean weight of $1.61 \mathrm{~g}$ ) per test was recorded. One possible explanation is that the deposits reflect a pre-1780 dump outside the east gate of the original compound. Exterior middens and trash deposits have been recorded at other missions in San Antonio (Clark 1978; Schuetz 1970).

Shovel test C6, about $15 \mathrm{ft}$ north of the east gate, contained the largest quantities of Colonial ceramics $(n=32)$ and animal bone fragments $(\mathrm{n}=283)$. Investigations of the plaza at Mission San José demonstrated that the association between Colonial period ceramics and high bone 
frequencies indicates a Colonial period origin for the bone (Hard et al. 1995). The concentration of post-Colonial ceramics in the southern portion of Mission Espada may reflect habitation sites along the south wall throughout the nineteenth and early twentieth centuries. More than 75 percent $(n=60)$ of the post-Colonial refined sherds were recovered from the southern half of the plaza (Rows 1-4). Shovel Test D1, located in the far southwestern corner of the New Plaza, contained the largest number of post-Colonial ceramics $(n=31)$.

The results of the shovel testing suggest that the northern portion of the New Plaza (Rows 5, 6, and 7) may contain intact Spanish colonial deposits. However, 6-12 inches of fill are currently being added to this portion of the plaza as part of a separate drainage improvement project at the mission. We recommend, therefore, that this northern area be avoided entirely until this land modification has been completed. The proposed disturbances will have no effect on Colonial deposits elsewhere in the plaza, and work should be allowed to continue in those areas. 


\section{References}

Balkwill, D. M., and S. L. Cumbaa

1992 A Guide to the Identification of Postcranial Bones of Bos taurus and Bison bison. Canadian Museum of Nature Syllogeus, No. 71, Ottawa.

Bolton, H. E.

1970[1915] Texas in the Middle Eighteenth Century. University of Texas Press, Austin.

Campbell, T. N., and T. J. Campbell

1985 Indian Groups Associated with Spanish Missions of the San Antonio Missions National Historical Park. Special Report, No. 16. Center for Archaeological Research, The University of Texas at San Antonio.

Chipman, D. E.

1992 Spanish Texas, 1518-1821. University of Texas Press, Austin.

Clark, J. W., Jr.

1978 Mission San José y San Miguel de Aguayo, Archeological Investigations, December 1974. Archeological Report 29. Texas Historical Commission, Austin.

Cook, G., and E. MacMillan

1980 San Antonio in 1776. In San Antonio in the Eighteenth Century, edited by E. MacMillan, pp. 129-135. Clarke, San Antonio.

Corner, W.

1890 San Antonio de Bexar: A Guide and History. Bainbridge and Corner, San Antonio.

Deagan, $\mathrm{K}$.

1987 Artifacts of the Spanish Colonies of Florida and the Caribbean, 1500-1800. Volume 1:

Ceramics, Glassware, and Beads. Smithsonian Institution, Washington, D. C.

Escobedo, S.

1984 Untitled Report on 1984 Excavations at Mission Espada. Copy on file at the Center for Archaeological Research, The University of Texas at San Antonio.

Fox, A. A.

1981 Test Excavations at Mission San Francisco de la Espada. Archaeological Survey Report, No. 108. Center for Archaeological Research, The University of Texas at San Antonio.

Fox, A. A., and T. R. Hester

1976 Archaeological Test Excavations at Mission San Francisco de la Espada. Archaeological Survey Report, No. 22. Center for Archaeological Research, The University of Texas at San Antonio.

Fox, A. A., F. A. Bass, and T. R. Hester

1976 The Archaeology and History of Alamo Plaza. Archaeological Survey Report, No. 16. Center for Archaeological Research, The University of Texas at San Antonio. 
Gilbert, B. M.

1990 Mammalian Osteology. Missouri Archaeological Society, Columbia.

Gilmore, K. K.

1969 The San Xavier Missions: A Study in Historical Site Identification. Report No. 16. State Building Commission Archeological Program, Austin.

Goggin, J. M.

1968 Spanish Majolica in the New World, Types of the Sixteenth to Eighteenth Centuries. Yale Publications in Anthropology 72. Department of Anthropology, Yale University, New Haven.

Habig, M. A.

1968 The Alamo Chain of Missions: A History of San Antonio's Five Old Missions. Franciscan Herald, Chicago.

Hard, R. J., A. A. Fox, I. W. Cox, K. J. Gross, B. A. Meissner, G. I. Méndez, C. L. Tennis, and J. E. Zapata

1995 Excavations at Mission San José y San Miguel de Aguayo, San Antonio, Texas. Archaeological Survey Report, No. 218. Center for Archaeological Report, The University of Texas at San Antonio.

Hillson, S.

1986 Teeth. Cambridge University Press, Cambridge.

Ivey, J. E., and A. A. Fox

1981 Archaeological Survey and Testing at Rancho de las Cabras, Wilson County, Texas. Archaeological Survey Report, No. 104. Center for Archaeological Research, The University of Texas at San Antonio.

1982 Archaeological Investigations at Mission Concepción and Mission Parkway. Archaeological Survey Report, No. 114. Center for Archaeological Research, The University of Texas at San Antonio.

Ivey, J. E., M. B. Thurber, and S. Escobedo

1990 Of Various Magnificence. The Architectural History of the San Antonio Missions in the Colonial Period and the Nineteenth Century. Two volumes. National Park Service Professional Papers No. 11. Santa Fe. Draft on file at the Center for Archaeological Research, The University of Texas at San Antonio.

Jones, O. L.

1979 Los Paisanos-Spanish Settlers on the Northern Frontier of New Spain. University of Oklahoma Press, Norman.

Killeen, K., and D. Scurlock

1986 A Report on Preliminary Test Excavations at Mission Espada Kilns, San Antonio, Texas. Manuscript on file. Center for Archaeological Research, The University of Texas at San Antonio. 
Lister, F. C., and R. H. Lister

1987 Andalusian Ceramics in Spain and New Spain. University of Arizona Press, Tucson.

Leutenegger, B., and C. Perry

1980 The Establishment of the Missions and the Work of the Missionary Fathers. In San Antonio in the Eighteenth Century, pp. 22-34. Clarke, San Antonio.

Meissner, B. A., K. J. Gross, and R. J. Hard

1996 Native American Settlement at the Spanish Colonial Mission of San José y San Miguel de Aguayo, San Antonio, Texas: A Faunal Analysis. Manuscript on file, Center for Archaeological Research, The University of Texas at San Antonio.

Meskill, F. K.

1992 Archaeological Testing within the Southeast Corner of the Plaza at Mission Espada, San Antonio, Bexar County, Texas. Archaeological Survey Report, No. 208. Center for Archaeological Research, The University of Texas at San Antonio.

Schuetz, M. K.

1970 Excavation of a Section of the Acequia Madre in Bexar County, Texas and Archeological Investigations at Mission San José in April 1968. Archeological Report No. 19. Texas Historical Survey Committee, Austin.

1980a Indians of the San Antonio Area. In San Antonio in the Eighteenth Century, edited by E. MacMillan, pp. 1-21. Clarke, San Antonio.

1980b The Mission Indians. In San Antonio in the Eighteenth Century, edited by E. MacMillan, pp. 35-46. Clarke, San Antonio.

1980c In the Period 1718-1731. In San Antonio in the Eighteenth Century, edited by E. MacMillan, pp. 73-83. Clarke, San Antonio.

Smith, H. P., Jr.

1980a Developmental Phases at Mission San Francisco de la Espada. La Tierra 7(4):36-39.

1980b Espada Mission, Research and Restoration. La Tierra 7(2):3-18.

Tunnell, C., and W. W. Newcomb, Jr.

1969 A Lipan Apache Mission, San Lorenzo de la Santa Cruz, 1762-1771. Bulletin of the Texas Memorial Museum 14, Austin.

Winfrey, D. H.

1965 San Francisco de Espada. In Six Missions of Texas, pp. 103-124. Texian, Waco, Texas. 